\title{
Assessment of youth involvement in yam production in Wukari local Government area of Taraba State, Nigeria
}

\author{
${ }^{1}$ Donye, A. O., ${ }^{2}$ Gwary, M. M., ${ }^{2}$ Nuhu, H. S. and ${ }^{2}$ Zhintswen, A. A. \\ ${ }^{1}$ Department of Agricultural Economics and Extension, Adamawa State University, Mubi \\ ${ }^{2}$ Department of Agricultural Extension Services, University of Maiduguri
}

\begin{abstract}
The study analyzed youth's involvement in yam production in Wukari Local Government Area of Taraba State, Nigeria. Data were collected using questionnaires which were administered to the respondents. A total of 90 youths involved in yam production were purposively selected and administered the questionnaires. Descriptive and inferential statistical tools such as frequency distribution, percentages and regression analysis were used for analyzing the data. The results revealed that majority of the respondents were within the age range of 31-40 years and male (70\%). With respect to their marital status $70 \%$ were single, while $30 \%$ were married. Also $33.3 \%$ of the youths had attained primary school education and the rest $(66.7 \%)$ had education above primary school level. Farm output of between 200-400 yam tubers was found to be the average yield while the annual income was between N30,000- N35,000. Results of the regression analysis show that farm size, marital status and income had significant relationships with the respondents' levels of yam production. They constituted the $R^{2}$ value of 0.956 . It was recommended that credit facilities should be provided to the youth. Modern farm inputs and implements should also be timely provided at affordable rates. Extension agents should be motivated to provide the required extension services to the youth involved in yam production.
\end{abstract}

Key words: Assessment, Youth Involvement, Yam, Production.

\section{INTRODUCTION}

Youth is a state of transition between childhood and adulthood characterized by the possession of attributes such as energy, intelligence and hope which enable the youth to improve their knowledge and capabilities (Erenie, 2002). The United Nation's Youth Agenda (UNYA) (2004) defined a youth as an individual between the ages of 15-24 years. The psychologist views the youth as an individual in whom there is time, energy and potentials which have not been fully utilized. Youths are those people with zeal, exuberance, dynamism and are volatile in nature.

Youths constitute about $40 \%$ of the Nigerian population (NPC, 2006) and are the major group much needed for agricultural transformation. In Nigeria, as in many countries of the world, it has been realized that government alone cannot provide for the needs of all the youths in the nation. Therefore, the involvement of youth in agriculture through which the spirit of self-help is promoted is of paramount importance. Youths can provide opportunities for the acquisition and development of valuable knowledge and skills, which have direct impact on them in terms of employment opportunities and economic viability.

Despite the roles played by most youths in their communities, some of them are being faced by series of problems (UNYA, 2004). The problems youth encounter are great challenges not only for the societies of today, but future generations are also affected. The United Nations Youth Empowerment Strategy (UNYES, 2002) reported that about seventysix million young people are unemployed throughout the world, representing more than $40 \%$ of the global unemployment. The report also indicated that more of the youths are being exploited (working for many hours with little gain) and no social protection in economy. In Nigeria, the unemployment situation is deteriorating every day (Central Bank of Nigeria, 2000). A survey by the National Manpower Board of 1990 showed that about 5.7 million graduates are unemployed, while the figure was predicted to hit 15 million by the end of 2005 (Oladoja et al, 2005).

In spite of the effort made by government, nongovernmental organizations and philanthropic individuals towards finding solutions to the problems of the youths and ensuring that their potentials are 
fully developed and directed towards national goals, there is still much more that need to be done. The problem of youths could be better solved through their involvement in economic and income-generating activities such as agricultural enterprises.

Yam is one of the important root crops in Nigerian. The demand for it is very high because its production is done only in some locations in the country where climatic conditions are favourable for its cultivation. This implies that the tuber crop could be a very good income earning crop as much as it is demanded by many Nigerians for consumption. It follows therefore, that this crop needs to be produced on large scale in order to meet the high demand of the Nigerian population. Since most Nigerian farmers are operating on subsistent levels of production, there is a serious need for cooperative or group approach. Yam production is labour intensive demanding a lot of energy. Youth are therefore, the most predisposed and fitted for its production.

Despite the fact that there exist some groups of youth that are involved in yam cultivation, only few studies that assessed the factors affecting its production were carried out on such groups. Also little research has been conducted on the involvement of youths in agricultural production in the study area. Therefore, this study was conducted to assess the participation of youth in yam production.

The main objective of the study was to assess youth's involvement in yam production in Wukari Local Government Area of Taraba State, Nigeria. The specific objectives were to:

identify the socio-economic characteristics of the respondents in the study area;

determine the level of youth's involvement in yam production in the study area;

identify the reasons for youth's involvement in yam production in the study area;

determine the constraints affecting the youths involved in yam production in the study area

The hypothesis stated and tested in the study is:

There is no significant relationship between the socio-economic characteristics of the respondents and the level of their involvement in yam production.

\section{METHODOLOGY}

The study was carried out in Wukari Local Government Area (LGA) of Taraba State, Nigeria. It is located between latitude $70^{\circ} \mathrm{N} 85^{\prime} \mathrm{E}$ and longitude $90^{\circ} \mathrm{N} 70^{\prime} \mathrm{E}$. It lies in the southern part of the guinea savannah vegetation zone. The study area has a land mass of about $4,308 \mathrm{~km}^{2}$ with a population of 24,546 (National Population Commission, 2006).

Sampling Procedure: The target population for the study were the youths at Wukari LGA. The local government consists of ten (10) districts and fourteen (14) wards. Multistage and purposive sampling procedures were employed in selecting the respondents for the study. In the first stage, five (5) districts were randomly selected from the ten existing ones. In the second stage, six (6) communities were also randomly selected from each district. The purposive sampling procedure was employed in the selection of fifteen (15) youths who were involved in the cultivation of yam from each of the selected communities. The total thus selected and administered a structured interview schedule was 90 youths.

Analytical Techniques: Both inferential and descriptive analytical techniques were used for the analysis of the data collected. The descriptive statistics used were frequencies and percentages, while the inferential tools of analysis used were correlation and multiple regression analyses.

The regression model used was given as: $Y=f\left(X_{1}, X_{2}\right.$ ............ $\mathrm{Xn}$ ), where:

$\mathrm{Y}=$ the level of involvement (indicated by the level of yam output in tubers)

$\mathrm{X}_{1}=$ years in formal school

$\mathrm{X}_{2}=$ farm size

$X_{3}=$ household

$\mathrm{X}_{4}=$ farming experience

$X_{5}=$ Annual farm income

\section{RESULTS AND DISCUSSION}

Socio-Economic Characteristics of the Respondents: The socio-economic characteristics of the respondents considered in this study were sex, age, marital status, educational level, family size, farming experience and annual income. Table 1 presents these characteristics and indicates that majority $(70 \%)$ of the respondents were males, while $30 \%$ were females. In most African countries, 
particularly Nigeria where the research was conducted, the provision of food and shelter is the responsibility of the man being the head of the house. It follows therefore, that the high percentage of young men involved in yam production was necessitated by their consciousness of such role. Besides, some of them explained through interview that apart from their struggle to satisfy their food needs, they needed money obtainable from yam production in order to support their education. This is also the reason for which the female young farmers decided to join their male counterparts in yam production in the area of study.

The table shows that majority (about $89 \%$ ) were within the agriculturally and economically productive age range of 18-50 years. This agrees with the FAO (1996) report that the age range of $15-60$ is economically productive. It is also in consonance with the finding of Ani (1999) who reported that the age of a farmer is very important in farming business as it entails experience. The older a farmer is, the more experience he has since he is expected to have acquired much farming techniques. Marital status of the respondents was also found to show an equal representation of the single, married and divorced, each of which constituted $30 \%$ of the distribution. This could be as a result of the productive age ranges to which most of them belong and is therefore, responsible for the even distribution.

The distribution of the respondents according to their educational level shows that most (33\%) of the respondents have attained secondary education. This is followed by those who have non-formal education $(24.4 \%)$ and then primary and higher education each of which constituted $21.1 \%$. The results show that all the respondents have one level of education or the other. This may not be unconnected with the fact that education plays a very prominent role among farmers as supported by the finding of Amaza and Tashikalma (2003), who noted that education offers the opportunities to earn better and could impact significant variation in skills acquisition and adoption of new ideas.

Analysis of the farming experience of the respondents also reveals that a high proportion
(45.6\%) of them had 6-10 years of farming experience. This implies that they have involved in yam cultivation for quite some time and must have reaped benefits from agricultural production. Adams (1982) also had a similar finding in which he reported that young people constitute a vital force for societal development. To him, other areas of activities suitable for youths are: recreational health programme, home making, vocational programmes, cultural activities, excursion etc. for the youths , therefore, to be involved in yam production is a decision brought about by the felt needs for food, healthy living and other social needs.

The table presents the distribution of the respondents based on their family size. Majority (40\%) of them were within the range of $2-4$, followed by those of less than two $(27.8 \%)$ people. This shows that most of the respondents involved in the production of yam belong to low number of family members. This could suggest that they have plans for their future, which they know for now depends on agriculture as their means of employment. Similarly, analysis of the income of the respondents revealed that majority $(40.0 \%)$ obtained between thirty to thirty-five thousand naira (N30, 000-N35, 000) annually. This may be considered as low income, which may not be unconnected with lack of proper and adequate resources/inputs such as money, land, fertilizers etc.

Table 2 shows the distribution of the respondents based on their level of output. A high proportion of them (33.30\%) indicated that they had yields between the ranges of 200-400 tubers of yam. Those of them that fell within the yield range of $401-700$ constituted $22.20 \%$, while $6.66 \%$ had more than 1000 tubers in a year. The likely reasons why most of the respondents had low yield could be attributed to their inability to adopt the innovative farming practices associated with yam production. Another possible reason might be the economic constraints that made them unable to acquire the required implements for yam cultivation as well as the failure to apply recommended inputs which could have raised their levels of output. 
Table 1: Distribution of the Respondents Based on Socio-economic Characteristics

\begin{tabular}{|c|c|c|}
\hline Sex & Frequency & Percentage \\
\hline Male & 63 & 70 \\
\hline Female & 27 & 30 \\
\hline \multicolumn{3}{|l|}{ Age (years) } \\
\hline$\leq 20$ & 13 & 14.4 \\
\hline $21-30$ & 20 & 22.2 \\
\hline $31-40$ & 29 & 32.2 \\
\hline $41-50$ & 18 & 20.0 \\
\hline Above 50 & 10 & 11.1 \\
\hline \multicolumn{3}{|l|}{ Marital Status } \\
\hline Single & 27 & 30 \\
\hline Married & 27 & 30 \\
\hline Widowed & 27 & 30 \\
\hline Divorced & 09 & 10 \\
\hline \multicolumn{3}{|l|}{ Educational Level } \\
\hline Non-formal education & 22 & 24.4 \\
\hline Primary education & 19 & 21.1 \\
\hline Secondary education & 30 & 33.3 \\
\hline Higher education & 19 & 21.1 \\
\hline \multicolumn{3}{|l|}{ Farming Experience } \\
\hline $1-5$ & 21 & 23.3 \\
\hline $6-10$ & 41 & 45.6 \\
\hline $11-15$ & 21 & 23.3 \\
\hline Above & 15 & 0.78 \\
\hline \multicolumn{3}{|l|}{ Family Size } \\
\hline Less than 2 & 25 & 27.8 \\
\hline $2-4$ & 36 & 40.0 \\
\hline $5-7$ & 18 & 20.0 \\
\hline $8-10$ & 11 & 12.2 \\
\hline \multicolumn{3}{|l|}{ Annual Income (N) } \\
\hline $20,000-25,000$ & 32 & 35.5 \\
\hline $26,000-30,000$ & 36 & 40.0 \\
\hline $31,000-35,000$ & 14 & 16.0 \\
\hline Above 35,000 & 08 & 09.0 \\
\hline Total & $\underline{90}$ & $\underline{100}$ \\
\hline
\end{tabular}

Source: Field Survey, 2010.

Table 2: Distribution of Respondents Based on Level of Output (number of tubers)

\begin{tabular}{|l|c|c|}
\hline No. Of tubers & Frequency & Percentage \\
\hline$<200$ & 20 & 22.20 \\
\hline $200-400$ & 30 & 33.30 \\
\hline $401-700$ & 20 & 22.20 \\
\hline $701-1000$ & 14 & 15.54 \\
\hline$>1000$ & 06 & 06.66 \\
\hline Total & $\mathbf{9 0}$ & $\mathbf{1 0 0 . 0}$ \\
\hline
\end{tabular}

Source: Field Survey, 2010. 
Involvement in Yam Production: Results of the study presented on Table 3 revealed that a high proportion $(51.11 \%)$ of the respondents involved in the yam production is using ordinary man-power to prepare their land areas for the cultivation. Others, constituting $31.11 \%$ use ox-drawn plough means for land preparation, $17.78 \%$ use farm machinery for the purpose of land preparation.

Table 3: Distribution of Respondents Based on Involvement in Yam Production

\begin{tabular}{|l|c|c|}
\hline Land Prep Means & Frequency & Percentage(\%) \\
\hline Use of man-power & 46 & 51.11 \\
\hline Use of farm machinery & 16 & 17.78 \\
\hline Use of ox-drawn plough & 28 & 31.11 \\
\hline Type of Labour & & 27.78 \\
\hline Self & 25 & 26.67 \\
\hline Hired labour & 24 & 24.44 \\
\hline Family labour & 22 & 21.09 \\
\hline Cooperative labour & 19 & $\mathbf{1 0 0}$ \\
\hline Total & $\mathbf{9 0}$ & \\
\hline
\end{tabular}

Source: Field Survey, 2010.

Table 3 also presents the distribution of the respondents on the basis of type of labour used. It indicated that $27.78 \%$ are engaged in self-labour, $26.67 \%$ use hired labour, $24.44 \%$ use family labour and those that use cooperative labour constituted $21.09 \%$. The results revealed that the youth involved in yam cultivation as individuals had the highest $(27.78 \%)$ percentage. This might be because, as young people, they have some ambitions set to be achieved in future and hence requires their active participation in order to actualize their expectations.

Distribution of Respondents Based on Reasons
for being Engaged in Yam Production: Table 4
presents the distribution of the respondents based on the various reasons for involvement in yam production. The results showed that $26.67 \%$ of the respondents got involved in yam production because they were influenced by their parents to do so. These might not have known that there is benefit in yam cultivation until when told by their parents. It is expected that when they enjoy the income from yam production they will continue to practice it henceforth. The results also revealed that $34.44 \%$ of the respondents decide to engage in yam production because they perceived it to be a good source of income and livelihood for them. This group could therefore, be said to be involved in order to make better their living standards. The lack of other preferable jobs to do was the reason why $23.33 \%$ of went into yam production. This means that they are not doing it as a matter of choice but circumstances made them to. However, it is expected that they will later continue to cultivate yam because of the money realized from it. Self-employment was the reason why $15.56 \%$ were involved in yam cultivation. This implies that they too know that agricultural production is an employment in itself from where they can earn their living so as to be self-reliant.

Constraints Faced by Respondents in Yam Production: Results on Table 5 show that majority $(22.22 \%$, with a rank value of 1$)$ of the respondents have limited access to credit facilities. This has been a major problem that hinders the yam farmers from attaining high productivity. Another constraint which also causes a great problem to the respondents is the market situation. They indicated that they have problems in the aspects of transportation of yam produce due to high cost as well as low prices for the commodity 
Agric. Biol. J. N. Am., 2012, 3(8): 311-317

Table 4: Distribution of Respondents Based on their Reasons for involvement in Yam

\begin{tabular}{|l|c|c|}
\hline & Frequency & Percentage (\%) \\
\hline Parental influence & 24 & 26.67 \\
\hline Source of income & 31 & 34.44 \\
\hline Lack of other preferable jobs & 21 & 23.33 \\
\hline Urge for self-reliance & 14 & 15.56 \\
\hline Total & $\mathbf{9 0}$ & $\mathbf{1 0 0}$ \\
\hline
\end{tabular}

Source: Field Survey, 2010

Table 5: Distribution of Respondents Based on Constraints in Yam Production

\begin{tabular}{|l|c|c|c|}
\hline Constraints & Frequency & Percentage (\%) & Rank \\
\hline Limited access to credit & 20 & 22.22 & 1 \\
\hline Market accessibility problem & 19 & 21.11 & 2 \\
\hline Lack of storage facility & 13 & 14.44 & 3 \\
\hline Problems of pests and diseases & 10 & 11.11 & 4 \\
\hline Poor transportation system & 08 & 08.11 & 6 \\
\hline Inadequate extension services & 06 & 06.89 & 7 \\
\hline High cost of local input & 05 & 05.56 & 8 \\
\hline Lack of modern implements & 04 & 04.44 & 9 \\
\hline Government policy & 03 & 03.33 & \\
\hline
\end{tabular}

Source: Field Survey, 2010

Regression Analysis of the Relationship between the Socio-economic Characteristics of Respondents and Output Level: The results of multiple regressions are presented on Table 6 . The double-log model results show the $R^{2}$ value was
0.956. This implies that $95.6 \%$ of the variations in the dependent variable (i.e. output level) were explained by the independent variables (i.e. the socio-economic characteristics).

Table 6: Regression Analysis

\begin{tabular}{|l|c|c|c|c|}
\hline Variable & Coefficient & Std. Error & T-Value & Significance \\
\hline Level of education & 0.047 & 0.137 & 2.037 & $0.035 \mathrm{NS}$ \\
\hline Farm size & 0.023 & 0.068 & 0.967 & $0.347 \mathrm{NS}$ \\
\hline Household size & -0.830 & 0.047 & -3.543 & $0.002 \mathrm{~S}$ \\
\hline Farming experience & 0.990 & 0.021 & 42.309 & $0.000 \mathrm{~S}$ \\
\hline Annual farm income & -0.040 & 0.010 & -1.758 & $0.081 \mathrm{NS}$ \\
\hline Constant & & 0.260 & -2.275 & \\
\hline
\end{tabular}

$R^{2}=0.956$

$\mathrm{R}^{2}$ (Adjusted) $=0.955$

Source: Field Survey, 2010.

Key: NS = Not Significant

$S=$ Significant at $1 \%$ level

Out of the five socio-economic characteristics considered for the regression, educational level, farm size and annual income of the respondents were found not to be significant. This implies that changes in these independent variables do not reflect any change in the output levels of the respondents. In the case of education and annual income, the reason for this could be that when the youths become more educated with the possibility of earning more income, they may tend to prefer other income-earning activities other than farming. For the farm size, it might be that a very large farm is not being managed well as well as being undersupplied with production inputs. However, household size and farming 
experience were found to be significant at $1 \%$ level each. This means that for every unit increase in the number of household members, there is also a corresponding increase in the output level of the respondents. Similarly, for every unit increase in the years of farming experience of the respondents, there is a reflection on the output level. In other words, for every increase in the years of farming experience of respondents, there is also an increase in the output level. This could be associated with the fact that they have acquired a lot of technical knowhow in yam production. The long time they have taken in yam cultivation could also enable them to gain knowledge from their contact with fellow farmers and extension agents, which when used in yam production accounts for the corresponding increase in output.

\section{CONCLUSION}

Majority of the youths involved in yam farming were within the agriculturally productive age range (31-40 years). The major occupation of majority of the respondents is farming although they operate on small farm sizes that range from 2-4 hectares. Major findings revealed that most of them carry out most farming operations using manual means. The major problems being encountered, among others, are limited access to financial credit, poor marketing systems and lack of good storage facilities. It was therefore, recommended among others that government and other non-governmental organizations should assist the young people in the area who have the interest to get fully involved in yam cultivation. Market outlets and systems should also be put in place for easy purchase as well as the sale of farm produce respectively.

\section{REFERENCES}

Adams, M. E. (1982). Agricultural Extension in Developing Countries. Longman Group Limited, pp. 53-58.

Ani, A.O. (1999): Analysis of the Performance of Rural Farmers in the Fadama Users' Association (FUA) Programme in the North Zone of Bauchi State Nigeria. Nigerian Journal of Tropical Agriculture: 36-40.

Amaza, P. S. And Tashikalma, A. K. (2003). Technical Efficiency in in Groundnut Production in Adamawa State, Nigeria. Journal of Arid Agriculture. Vol. 13, pp. 67-90.

Central Bank of Nigeria (CBN), (2000). Central Bank of Nigeria Statistical Bulleting, Lagos.

Erenie, S. (2002). Youth, a Stronghold for Sustainable Agricultural Extension Delivery and Development. Proceeding of the $8^{\text {th }}$ Annual Conference of agricultural Extension Society of Nigeria. September $13^{\text {th }},-17^{\text {th }}$. Pp.15-20.

Food and Agriculture Organization (FAO), (1996). Energy Sustainable Development and Food Security in Africa. United Nations Conference on Environment and Development, Rome.

National Population Commission (NPC), (2006). Analytical Report of National Level. Omnia Press, Lagos.

Oladoja, M. A., Adeokun, O. A. and Adisa, B. O. (2005). Agricultural Extension and Poverty Alleviation. Problems and Challenges in Democratic and Deregulated Economy. Journal of Agriculture. Vol. 8, pp. 84-89.

United Nations Youth Agenda (UNYA), (2004). Empowering for Development and Peace.

http://www.un.org/youth.

United Nations Youth Empowerment Strategy (UNYES), (2002).

http://www.un.org/esa/socdev/un/forum/do/can/doc 